\title{
Total Dietary Fats, Fatty Acids, and Omega-3/Omega-6 Ratio as Risk Factors of Breast Cancer in the Polish Population - a Case-Control Study
}

\author{
DOROTA DYDJOW-BENDEK and PAWEL ZAGOŹDŹON \\ Department of Hygiene and Epidemiology, Medical University of Gdansk, Gdansk, Poland
}

\begin{abstract}
Background/Aim: Breast cancer is the most common type of cancer among women around the world and the leading cause of cancer-related death among women. The knowledge about modifiable risk factors, such as diet, can be an acceptable, cheap and non-pharmacological prevention tool. The aim of this study was to investigate the association between dietary fat, dietary fatty acids, fish intake, and breast cancer in women. Patients and Methods: A case-control study was designed. A total of 201 consecutive, newly diagnosed, polish female cancer patients (mean age: 58 years) and 201 one-to-one age-matched controls were enrolled. A standardised questionnaire assessing various sociodemographic, clinical, lifestyle, and dietary characteristics was applied via face-to-face interviews. Detailed dietary intake information was assessed using a validated Food Frequency Questionnaire. Odds ratios (OR) and 95\% confidence intervals (95\%CI) were obtained using multiple unconditional logistic regression models controlling for nondietary and dietary potential confounders. Results: Consumption of polyunsaturated fats (PUFA) over $10 \%$ of total energy intake was associated with a significantly lower risk of breast cancer compared to low intake of PUFA $(O R=0.4,95 \% C I=0.19-0.85)$. Low $(<0.2)$ omega-3/ omega6 ratio $(O R=2.04,95 \% C I=0.996-4.17)$, fish consumption less than once every six months $(O R=3.37,95 \% C I=1.57-7.23)$ and being overweight (OR=2.07, 95\%CI=1.3-3.3) were associated with increased risk of breast cancer. Residents of rural areas had a significantly higher risk compared to
\end{abstract}

This article is freely accessible online.

Correspondence to: Dorota Dydjow-Bendek, Department of Hygiene and Epidemiology, Medical University of Gdańsk, Dębinki Street 7/15, 80-211 Gdansk, Poland. Tel: +48 583491820, e-mail: dbendek@gumed.edu.pl

Key Words: Breast cancer, dietary fat, fish intake, omega-3/omega6 ratio, case-control study, women's health. women from urban areas $(O R=1.8,95 \% C I=1.06-3.03)$. Conclusion: High intake of PUFA can decrease the risk of breast cancer, while the low omega-3/omega-6 ratio increases the risk. In addition, overweight state, eliminating fish from the diet and living in rural areas can also increase the risk of breast cancer.

Breast cancer is the most common type of cancer among women around the world and the leading cause of cancerrelated death among women. In 2018, 2.1 million new cases were diagnosed worldwide, while in the same year breast cancer was the cause of approximately 627 thousand deaths (1-3). In Poland the number of newly registered cases is constantly growing (4). Every year 18 thousand women are diagnosed with breast cancer, which accounts for $22 \%$ of all types of cancer among Polish women $(5,6)$.

While known risk factors for breast cancer, such as: age over 40 years, positive family history, early menstruation, late menopause, late age of first pregnancy (after the age of 35 years), duration of breastfeeding, and Caucasian race ( 7 , 8) are basically unmodifiable, the knowledge of nutritional recommendations and the awareness that the diet has an impact on the risk of developing this type of cancer $(7,9)$ may be harbingers of a new primary prevention system. Many studies have drawn special attention to dietary fat and fatty acids (10-14); however, they do not provide a definitive answer to the question of the role of fat in the aetiology of breast cancer. The western diet, characteristic for the Polish population, is characterised by a low supply of omega-3 fatty acids and high omega- 6 fatty acids. In the coastal side of Poland, fish consumption is low and decreasing year by year. This is largely due to the lack of awareness about the health properties and their relatively high price.

Until now, to our knowledge, the omega-3/omega-6 ratio in the context of breast cancer has not been analysed in the Polish population. The aim of our study was to assess the effect of total, saturated, and unsaturated fatty acids, cholesterol, omega3 and omega- 6 acids, and fish consumption on the risk of breast cancer. 


\section{Patients and Methods}

This study was based on a case-control scheme with face-to-face interviews with the participants. Caucasian women diagnosed with incident, primary, and histologically-confirmed breast cancer $(n=201)$ were hospitalised in the Oncological Surgery Clinic of the Medical University of Gdansk during the period from 01.2015 to 06.2017 , while the diagnosis took place in the period no longer than three months preceding the study. Patients diagnosed more than three months in advance were not included (in order to avoid changes in their dietary habits or other behaviours). The other inclusion criteria for cases were: i) age between 50 and 69 years old, ii) agreement to participate and iii) ability to understand and answer the questionnaire. Women previously diagnosed with breast cancer and women who were unable to answer the questionnaire due to health, language or educational issues were excluded. Community controls included neighbourhood residents of the BCA cases, who had no self-reported breast cancer (e.g. had never been told by a doctor or health-care worker that they may be checked for breast cancer). Interviewers visited the selected control subjects or asked to fill the questionnaire and return by post. Control subjects were matched by age ( \pm 5 years), and socio-economic status (SES) to the corresponding case subjects. If a suitable control subject could not be located in the BCA community, the researchers tried to find the appropriate control using their own social contacts (this occurred in $20 \%$ of cases).

The study was approved by the Bioethical Commission of the Medical University of Gdansk number NKBBN/47/2014. Prior to the collection of any information, participants were informed about the aim and procedures of the study and provided their signed consent. After receiving the informed consent of the participants for the study, interviews were conducted on known and suspected breast cancer factors.

Dietary Assessment. A comprehensive Food Frequency Questionnaire (FFQ) was carried out in the study group by the interviewer. The patients received a second copy of the same questionnaire (in a freepost envelope) in order to pass it on to an unrelated, healthy woman (without breast cancer), approximately the same age ( $\geq 50$ years old), living in the same town, and leading a similar lifestyle. Such a selection of the control group guaranteed minimisation of disturbances related to the socio-economic status. Participants were asked about the usual consumption of about 110 products divided into groups: i) alcoholic and non-alcoholic beverages (and additives like sugar, sweetener), ii) fruits, iii) vegetables, iv) fats, v) cereals, vi) meat, vii) poultry, viii) fish, dairy products, sweets, crisps, soy products, and eggs, as well as dietary supplements, during the year preceding the test (for example: never, less than once every six months, once every 3-4 months, once a month, 1-2 times a week, every day). The questionnaire included the most commonly consumed products in Poland with the possibility of supplementing with other unlisted ones. The size of the portions, using food models and the frequency of consumption, were evaluated to estimate grams of intake.

Other measurements. The second part of the questionnaire provided knowledge about age and place of residence (city-village). Data on height and body weight were used to calculate body mass index (BMI) according to the procedure: weight in kilograms divided by height in metres squared. BMI was defined as normal body weight and overweight $(\leq 29.99)$ and obese $(\geq 30)$. Participants of the study were asked about physical activity: i) daily physical activity was classified as high, ii) 2-3 times per week was classified as moderate, and iii) once a month or less frequently as lack of activity. Smoking cigarettes (current and former smoking, total years of smoking, and number of cigarettes smoked per day) were also recorded. Family history of breast cancer, gynaecological medical history (i.e. age of menarche $(\leq 12 />12)$, age of menopause $(\leq 55 />55)$, use of hormone replacement therapy-HRT) as well as the age of the first pregnancy, miscarriage/aborting the pregnancy, number of children, and duration of breastfeeding were recorded during the interview. The questionnaire also provided information on the occurrence of mononucleosis and exposure to ionising radiation during early childhood. These factors were selected among lifestyle-related variables because they have been reported to be risk factors for breast cancer (15).

Statistical analysis. After calculating the daily amounts of food consumed, the data from the FFQ questionnaire were introduced into the computer program "Diet-Pro" (Jacek Kwiatkowski Computer Services Company), which quickly calculates the dietary content of 83 nutrients (proteins, carbohydrates, total fats, fatty acids including omega- 3 and omega- 6 , fibre, vitamins, and minerals) along with the reference values and the Glycaemic Index (IG). The results of nutritional analysis were exported to Microsoft Excel and then to the Statistica 13 software. Continuous variables that were normally distributed were presented as mean \pm SD. Normality was evaluated using the P-P plots. Student's $t$-test for independent samples was used to evaluate the mean differences of the normally distributed variables (i.e. BMI) between cases and controls, and in the case of skewed variables, the tested hypothesis was evaluated using the nonparametric $U$-test suggested by Mann and Whitney. The results are presented in Table I. The average daily amounts of consumed ingredients are presented in Table II. Multivariate logistic regression was used to assess the relationship between the diet, with particular reference to total saturated and unsaturated fats and individual fatty acids, and the occurrence of breast cancer (Tables III, IV). The analysis was adjusted for potential disruptive factors such as: i) age, ii) place of residence, iii) BMI $\left(\mathrm{kg} / \mathrm{m}^{2}\right)$, iv) history of smoking, $\mathrm{v}$ ) drinking over $12 \mathrm{~g}$ of alcohol/day, vi) physical activity (no activity, moderate), vii) family history of breast cancer incidence, viii) age of menarche, ix) age of first pregnancy, $x$ ) childhood diseases - among others mononucleosis, and xi) the use of HRT. The variables for the model were selected using backward step regression. Finally, the model included variables at $p \leq 0.05$. The results of logistic regression are presented as an odds ratio with a $95 \%$ confidence interval $(95 \% \mathrm{CI})$.

\section{Results}

The basic characteristics of patients and controls are presented in Table I. Cases and controls were of similar age (mean age: $58 \pm 6$ years old). Cases compared to the control group had a less frequently declared breastfeeding $(63.18 \%$ vs. $73.63 \%, p=0.02)$ and were more often obese compared to healthy women $(34 \%$ vs. $20 \%, p=0.016$ ). With regard to the main research hypothesis, a strong association between fish consumption and the presence of breast cancer was observed. In particular, cases were more likely to consume less fish compared to controls; $15.4 \%$ of cases 
Table I. Characteristics of the cases and controls by socio-demographic and selected variables.

\begin{tabular}{|c|c|c|c|c|c|}
\hline \multirow{2}{*}{$\begin{array}{l}\text { Age (years) mean } \pm \text { SD } \\
\text { Characteristics }\end{array}$} & \multicolumn{2}{|c|}{$\begin{array}{c}\text { Cases } \\
59 \pm 6\end{array}$} & \multicolumn{2}{|c|}{$\begin{array}{c}\text { Controls } \\
58 \pm 6\end{array}$} & \multirow[t]{2}{*}{$p$-Value } \\
\hline & $\mathrm{n}$ & $\%$ & $\mathrm{n}$ & $\%$ & \\
\hline \multicolumn{6}{|l|}{ Ionising radiation in childhood } \\
\hline Yes & 13 & $6.47 \%$ & 5 & $2.49 \%$ & 0.48 \\
\hline No & 167 & $83.08 \%$ & 176 & $87.56 \%$ & \\
\hline I don't know & 21 & $10.45 \%$ & 20 & $9.95 \%$ & \\
\hline \multicolumn{6}{|l|}{ Physical activity } \\
\hline No & 102 & $51 \%$ & 110 & $55 \%$ & \\
\hline Moderate & 63 & $31 \%$ & 50 & $25 \%$ & 0.7 \\
\hline High & 36 & $18 \%$ & 41 & $20 \%$ & \\
\hline \multicolumn{6}{|l|}{ Smoking } \\
\hline Never & 85 & $43 \%$ & 90 & $45 \%$ & \\
\hline Former & 86 & $43 \%$ & 69 & $34 \%$ & 0.3 \\
\hline Active & 30 & $14 \%$ & 42 & $21 \%$ & \\
\hline \multicolumn{6}{|l|}{ Alcohol intake } \\
\hline$\leq 12 \mathrm{~g} /$ day & 186 & $92.5 \%$ & 191 & $95 \%$ & 0.3 \\
\hline$>12$ g/day & 15 & $7.5 \%$ & 10 & $5 \%$ & \\
\hline Age at menarche (years) & & & & & 0.9 \\
\hline$\leq 12$ & 39 & $19 \%$ & 40 & $20 \%$ & \\
\hline$>12$ & 162 & $81 \%$ & 161 & $80 \%$ & \\
\hline Mononucleosis in childhood & & & & & 0.5 \\
\hline Yes & 3 & $1.5 \%$ & 3 & $1.5 \%$ & \\
\hline No & 171 & $85 \%$ & 178 & $88.5 \%$ & \\
\hline I don't know & 27 & $13.5 \%$ & 20 & $10 \%$ & \\
\hline Number of live births & & & & & 0.9 \\
\hline 0 & 34 & $17 \%$ & 25 & $12 \%$ & \\
\hline 1 & 44 & $22 \%$ & 53 & $26 \%$ & \\
\hline 2 & 73 & $36 \%$ & 77 & $38 \%$ & \\
\hline 3 & 29 & $14 \%$ & 28 & $14 \%$ & \\
\hline$\geq 4$ & 21 & $11 \%$ & 18 & $10 \%$ & \\
\hline Breastfeeding & & & & & 0.02 \\
\hline Yes & 127 & $63.18 \%$ & 148 & $73.63 \%$ & \\
\hline No & 74 & $36.82 \%$ & 53 & $26.37 \%$ & \\
\hline HRT (Hormon Replacement Therapy) & & & & & 0.06 \\
\hline Yes & 54 & $27 \%$ & 38 & $19 \%$ & \\
\hline No & 147 & $73 \%$ & 163 & $81 \%$ & \\
\hline Age of menopause: & & & & & 0.9 \\
\hline Premenopausal & 41 & $20 \%$ & 52 & $26 \%$ & \\
\hline$\leq 55$ & 98 & $49 \%$ & 98 & $49 \%$ & \\
\hline$>55$ & 62 & $31 \%$ & 51 & $25 \%$ & \\
\hline Family history of breast cancer: & & & & & 0.4 \\
\hline Yes & 52 & $26 \%$ & 45 & $22 \%$ & \\
\hline No & 149 & $74 \%$ & 156 & $78 \%$ & \\
\hline Family history of breast cancer at $<55$ years old & & & & & 0.2 \\
\hline Yes & 30 & $15 \%$ & 21 & $10 \%$ & \\
\hline No & 171 & $85 \%$ & 180 & $80 \%$ & \\
\hline Residence area: & & & & & 0.01 \\
\hline Urban & 151 & $75 \%$ & 171 & $85 \%$ & \\
\hline Rural & 50 & $25 \%$ & 30 & $15 \%$ & \\
\hline BMI & & & & & 0.02 \\
\hline$\leq 29,99$ & 133 & $66 \%$ & 161 & $80 \%$ & \\
\hline$\geq 30$ & 68 & $34 \%$ & 40 & $20 \%$ & \\
\hline Fish intake & & & & & 0.001 \\
\hline Yes & 170 & $84.6 \%$ & 191 & $95 \%$ & \\
\hline No & 31 & $15.4 \%$ & 10 & $5 \%$ & \\
\hline
\end{tabular}

*Reported $p$-Values were calculated using t test or Mann-Whitney $U$-test. 
Table II. Average daily amounts of ingredients consumed.

\begin{tabular}{lccc}
\hline & Cases & Controls & $p$-Value \\
\hline Energy (kcal) & $1721 \pm 538$ & $1710 \pm 532$ & 0.9 \\
Energy from fat \% & $34 \%$ & $33 \%$ & 0.8 \\
Saturated fat (g) & $23.4 \pm 9.6$ & $23.2 \pm 9.3$ & 0.8 \\
MUFA (g) & $25.9 \pm 8.8$ & $25.4 \pm 9.2$ & 0.6 \\
PUFA (g) & $11 \pm 3.8$ & $11 \pm 3.9$ & 0.6 \\
Omega 3 (g) & $2 \pm 1$ & $1.9 \pm 1$ & 0.09 \\
Omega 6 (g) & $9.3 \pm 3.3$ & $9.2 \pm 3.3$ & 0.7 \\
Omega-3/omega-6 & $0.23 \pm 0.1$ & $0.2 \pm 0.1$ & 0.9 \\
Cholesterol (mg) & $287 \pm 115$ & $279 \pm 122$ & 0.5 \\
\hline
\end{tabular}

vs. 5\% in the control group did not consume any fish at all $(p=0.001)$. Residents of rural areas had a significantly higher risk compared to women from urban areas $(\mathrm{OR}=1.8,95 \% \mathrm{CI}=1.06$ 3.03). There were no statistically significant differences regarding smoking, alcohol consumption, physical activity, or menopausal status. Women from both groups were also characterised by a similar family history (occurrence of breast cancer in the family, as well as pathologies predisposing them to the disease, i.e. hereditary breast cancer - site-specific, breast cancer-ovarian cancer syndrome, Li-Fraumeni syndrome, Lynch II syndrome, Cowden's disease, Peutz-Jaeghers syndrome, ataxia-telangiectasia, Klinefelter syndrome (16). It is also worth noting that the use of HRT by women $(\mathrm{OR}=1.6,95 \% \mathrm{CI}=0.98$ $2.52, p=0.06$ ) - perhaps with a larger population it would turn out to be significant - is higher in comparison to women who had not used HRT. In any case, this matter should be subjected to further analysis with a larger cohort. Analysis of diet using the Diet-Pro software provided information on the total average daily energy ( $\mathrm{kcal} / \mathrm{day}$ ) and fats (total amount, saturated, unsaturated, cholesterol, MUFA, PUFA - omega-3, and omega6). There were no statistically significant differences for individual fat components in the diet (Table II). Results of univariate and multivariate logistic regression analysis assessing the association between risk factors and breast cancer are presented in Table III.

The univariate analysis did not show a relationship between PUFA and omega-3/omega- 6 ratio and risk of breast cancer. The study also did not show a relationship between the total dietary fat, saturated and unsaturated fats altogether, cholesterol, protein, fibre, vitamins A, D, E, folate and microelements in the diet. The analysis showed that high intake of Vitamin B12 was significantly associated with increased risk of breast cancer $(\mathrm{OR}=2.13,95 \% \mathrm{CI}=0.99-4.56$, $p=0.05$ ) (Table III).

Fat and fish consumption and breast cancer. Odds ratios calculated in a multivariate analysis (Table IV) showed a statistically significant relationship between consumption of
PUFA (OR $=0.4,95 \% \mathrm{CI}=0.19-0.85, p=0.02)$, low omega3/omega-6 ratio $(\mathrm{OR}=2.04,95 \% \mathrm{CI}=0.996-4.17, p=0.05)$, eliminating fish from the diet $(\mathrm{OR}=3.37,95 \% \mathrm{CI}=1.57-7.23$, $p=0.002)$, being overweight $(\mathrm{OR}=2.07,95 \% \mathrm{CI}=1.3-3.3$, $p=0.002$ ) and the risk of breast cancer. PUFA intake $\geq 10 \%$ of the total daily amount of energy was associated with a reducing risk by $60 \%$ compared to women with a daily consumption of PUFA covering less than $10 \%$ of the total daily amount of energy. At the same time, low omega3/omega-6 ratio $(<0.2)$ and being overweight $(\mathrm{BMI} \geq 30)$ both gave a two-fold increase in risk, while eliminating fish from the diet (regardless of frequency of intake) was associated with a 3.37 -fold increase in the risk of breast cancer.

\section{Discussion}

The relationship between fat consumption and the risk of breast cancer is still very controversial. Scientists have been interested in this topic for many decades. The origins of research date back to the 1970s and were undertaken due to the high global variability of breast cancer incidence (17). Looking for the reason of this phenomenon, attention was paid to differences in fat consumption per capita in the word. An important role was also played by changes in the incidence of breast cancer among Japanese immigrants. There have been more frequent cases of this disease compared to the incidence of breast cancer in Japan (18-21). A meta-analysis of studies, carried out in the 1990s, suggested a potential relationship between high fat consumption and an increased risk of breast cancer (22).

In a case-control study, the characteristics of the control group were compared with those of the Polish population from which certain cases were selected $(23,24)$ to exclude the possibility of a selection bias. This study showed that low omega-3/omega-6 ratio was associated with increased a risk of the disease. A similar correlation also concerning high BMI. There was no relationship between the total dietary fat, saturated, unsaturated, and monounsaturated fatty acids and cholesterol in the diet of the study participants. Studies conducted previously, similarly to our study, showed that a high omega-3/omega-6 ratio is associated with a lower risk of breast cancer (25-32). This result was also obtained in Tolland County in USA $(\mathrm{OR}=0.50,95 \% \mathrm{CI}=0.27-0.95)$ - a case-control study conducted in Mexico has shown that high omega-3/omega-6 ratio is associated with lower risk in obese women $(p=0.01)(33)$. Whereas there are other studies that have not shown such a correlation $(34,35)$. A prospective study conducted in Singapore that included 35298 women aged 45-74 years showed an inverse relationship between high intake of fatty acids and incidence of breast cancer (relative risk $(\mathrm{RR})=0.74,95 \% \mathrm{CI}=0.58-0.94)$. Similar to our study, several of the previously performed analyses have not shown a statistically significant relationship between dietary 
Table III. Results of univariate and multivariate logistic regression analysis assessing the association between risk factors and breast cancer.

\begin{tabular}{|c|c|c|c|c|}
\hline & $\begin{array}{l}\text { Univariate OR } \\
\quad(95 \% \mathrm{CI})\end{array}$ & $p$-Value & $\begin{array}{c}\text { Multivariate OR } \\
\quad(95 \% \mathrm{CI})\end{array}$ & $p$-Value \\
\hline Alcohol intake $\geq 12 \mathrm{~g} /$ day & $1.54(0.67-3.51)$ & 0.3 & $1.18(0.44-3.17)$ & 0.74 \\
\hline Physical activity (yes/no) & $1.17(0.71-1.93)$ & 0.53 & $1.12(0.64-1.96)$ & 0.69 \\
\hline Smoking (yes or former) & $1.1(0.75-1.64)$ & 0.6 & $1.23(0.79-1.93)$ & 0.36 \\
\hline Ionising radiation in childhood & $2.75(0.96-7.88)$ & 0.06 & $2.39(0.75-7.59)$ & 0.14 \\
\hline Mononucleosis in childhood & $1.33(0.76-2.35)$ & 0.32 & $1.19(0.62-2.3)$ & 0.6 \\
\hline Age at menarche (years) $>12$ & $1.03(0.63-1.69)$ & 0.9 & $1.3(0.73-2.24)$ & 0.39 \\
\hline Resignation from breastfeeding & $1.67(1.06-2.49)$ & 0.02 & $1.47(0.9-2.4)$ & 0.12 \\
\hline Miscarriage & $1.12(0.7-1.8)$ & 0.63 & $1.16(0.68-1.99)$ & 0.58 \\
\hline HRT (Hormon Replacement Therapy) & $1.6(0.98-2.52)$ & 0.06 & $1.63(0.95-2.79)$ & 0.07 \\
\hline Family history of breast cancer & $1.2(0.76-1.91)$ & 0.41 & $1.03(0.53-1.97)$ & 0.94 \\
\hline Family history of breast cancer at $<55$ years old & $1.5(0.83-2.73)$ & 0.18 & $1.47(0.62-3.48)$ & 0.38 \\
\hline Menopause & $0.98(0.66-1.45)$ & 0.92 & $0.84(0.53-1.32)$ & 0.44 \\
\hline Living in the rural aera & $1.94(1.17-3.2)$ & 0.009 & $1.85(1.03-3.33)$ & 0.04 \\
\hline Energy request $>30 \mathrm{kcal} / \mathrm{kg}$ body mass & $1.13(0.73-1.74)$ & 0.58 & $0.94(0.48-1.83)$ & 0.86 \\
\hline Protein intake $>1 \mathrm{~g} / \mathrm{kg}$ body mass & $1.14(0.73-1.79)$ & 0.56 & $1.015(0.43-2.4)$ & 0.97 \\
\hline Fibre intake $<20 \mathrm{~g} /$ day & $1.35(0.91-2.0)$ & 0.13 & $1.31(0.71-2.41)$ & 0.38 \\
\hline Calcium intake $<1200 \mathrm{mg} /$ day & $0.95(0.63-1.45)$ & 0.83 & $1.01(0.55-1.83)$ & 0.98 \\
\hline Iron intake $<8 \mathrm{mg} /$ day & $0.78(0.48-1.27)$ & 0.32 & $0.69(0.3-1.59)$ & 0.39 \\
\hline Zinc intake $<8 \mathrm{mg} /$ day & $0.94(0.59-1.5)$ & 0.81 & $1.84(0.76-4.42)$ & 0.17 \\
\hline Manganese intake $>2.5 \mathrm{mg} /$ day & $1.15(0.68-1.92)$ & 0.6 & $0.94(0.46-1.89)$ & 0.86 \\
\hline Vitamin A intake $>600 \mu \mathrm{g} /$ day & $1.55(0.83-2.88)$ & 0.16 & $1.54(0.7-3.42)$ & 0.28 \\
\hline Vitamin $D$ intake $<10 \mu \mathrm{g} /$ day & $0.65(0.3-1.34)$ & 0.26 & $0.78(0.33-1.85)$ & 0.57 \\
\hline Vitamin $\mathrm{E}$ intake $<8 \mathrm{mg} /$ day & $0.81(0.54-1.21)$ & 0.3 & $0.88(0.5-1.53)$ & 0.65 \\
\hline Folate intake $<320 \mu \mathrm{g} /$ day & $0.74(0.5-1.11)$ & 0.15 & $0.98(0.51-1.91)$ & 0.96 \\
\hline Vitamin B12 intake $>2 \mu \mathrm{g} /$ day & $1.7(1.04-2.8)$ & 0.03 & $2.13(0.99-4.56)$ & 0.05 \\
\hline Saturated fat $\geq 6 \%$ of total energy intake & $1.06(0.66-1.68)$ & 0.81 & $1.02(0.51-2.03)$ & 0.95 \\
\hline Omega $3<1 \mathrm{~g} /$ day & $0.64(0.35-1.16)$ & 0.14 & $1.05(0.48-2.31)$ & 0.9 \\
\hline Omega $6>4 \%$ of total energy intake & $1.08(0.69-1.68)$ & 0.73 & $1.06(0.62-1.81)$ & 0.84 \\
\hline Cholesterol $\leq 350 \mathrm{mg} /$ day & $0.94(0.63-1.4)$ & 0.76 & $0.6(0.34-1.04)$ & 0.07 \\
\hline $\mathrm{BMI} \geq 30$ & $2.06(1.3-3.24)$ & 0.002 & $2.27(1.36-3.79)$ & 0.002 \\
\hline Omega-3/omega- $6<0.2$ & $1.02(0.68-1.51)$ & 0.92 & $1.72(0.74-3.79)$ & 0.17 \\
\hline PUFA $\geq 10 \%$ total energy intake & $0.7(0.48-1.1)$ & 0.14 & $0,42(0.18-0.98)$ & 0.04 \\
\hline Eliminating fish from the diet & $3.48(1.66-7.32)$ & 0.001 & $3.58(1.59-8.08)$ & 0.002 \\
\hline
\end{tabular}

OR: Odds ratio; CI: confidence interval.

fat, saturated and unsaturated fatty acids, and breast cancer (27, 36-40). However, in a study conducted in Poland in the Pomorskie Voivodeship between 1999-2006, a positive relationship was found between high total saturated fatty acids intake and breast cancer $(\mathrm{OR}=1.66,95 \% \mathrm{CI}=1.07-3.59)$ (41). A similar result was obtained in a case-control study conducted in Taiwan $-\mathrm{OR}=2.6,95 \% \mathrm{CI}=1.4-5.0$ (42). Other results were provided by a study conducted in New York, where it was estimated that high consumption of PUFA, omega- 3 , and omega- 6 is associated with an increased risk of breast cancer $(\mathrm{OR}=1.25)$; on the other hand, no relationship was found between omega-3/omega- 6 ratio alone and breast cancer (43). Interestingly, a reduced risk was estimated in the case of low supply of omega-3 and omega- 6 in total $(\mathrm{OR}=0.83,95 \% \mathrm{CI}=0.63-1.09)$. In a study conducted in Shanghai, high intake of omega- 6 with a simultaneous low intake of omega-3 was associated with a two-fold higher risk
Table IV. Odds ratios (ORs) of breast cancer for different types of fats.

\begin{tabular}{lcc}
\hline & Multivariate OR (95\%CI) & $p$-Value \\
\hline omega-3/omega-6 <0.2 & $2.04(0.99-4.17)$ & 0.05 \\
PUFA $\geq 10 \%$ total energy intake & $0.4(0.19-0.85)$ & 0.02 \\
Eliminating fish from the diet & $3.37(1.57-7.23)$ & 0.002
\end{tabular}

OR: Odds ratio; CI: confidence interval.

of disease (25). The EPIC study showed a small but significant relationship between the total consumption of saturated fatty acids and an increased risk of breast cancer (5). The results of the Women's Health Initiative Dietary Modification Trial suggested that reducing the total dietary fat may reduce the risk by $9 \%$ (but this comparison did not show any statistical significance) (44). Some additional 
prospective studies have not shown a relation between dietary fat and risk of breast cancer (35); however, a meta-analysis of 45 case-control studies has shown an increased risk with dietary total fat and saturated fatty acids (45).

Summing up, the results from this study suggest that a high omega-3/omega-6 ratio, optimal body weight, and fish as part of the diet can be a first step towards breast cancer prevention in Poland. In addition, consumption of PUFA $\geq 10 \%$ of the total daily energy can decrease the risk. Several sources of information suggest that people have evolved on a diet with a ratio of omega-3/omega- 6 fatty acids of $\sim 1$, while today in western diets (also in Poland) this ratio is $1 / 15-1 / 30$. The average diet in developed countries is characterised by low supply of omega-3 fatty acids (found in fish) and excessive amounts of omega-6 fatty acids (found in vegetable oils, i.e. sunflower, as well as in corn, eggs and meat) in comparison to the ancestral diet, on which human genetic patterns were established (12). Many studies indicate that polyunsaturated fatty acids from the omega- 6 family can stimulate the process of cancer, while omega-3 fatty acids can contribute to the reduction of the incidence of malignant tumours, including breast cancer (46). Excess of vegetable oils in the diet with a simultaneous low supply of fish may lead to an abnormal omega-3/omega-6 indicator (12). Breast cancer nutritional prophylaxis should be based largely on a high inclusion of fish in the diet, especially seawater fish, such as mackerel, tuna, salmon, or herring (47). The protective influence is induced by consumption of at least two portions per week, although in this studied population it turned out that supplementing the menu with fish once a month compared to total exclusion from the menu plays a significant role towards the prevention of breast cancer. Unfortunately, in Poland, the consumption of sea fish is decreasing every year (48). This is probably related to the relatively high price of fish compared to meat and the lack of public awareness on the health benefits from fish. Possibly associated with low fish consumption may also be the fact that there is fear of pollution in the sea; however, many studies have shown that the health benefits of eating fish to a large extent outweigh the risks (49).

It is also worth paying attention to vegetable sources of omega-3, i.e. linseed and chia seeds. An addition of 1 tbsp daily, for example to yogurt or porridge will supplement the daily demand for these fatty acids. Other sources of omega-3 fatty acids primarily include: walnuts, linseed and hemp oil, seafood, and soy products. Increasing the consumption of these products while limiting vegetable oils, full-fat milk products, and red meat should be the foundation of the diet of every woman who cares about her health (50). It is also worth noting that a diet taking into account an adequate supply of omega-3 fatty acids is also an element of prevention of obesity, which is not only a disease in itself, but is also an important risk factor for cancer - including breast cancer (51). Similar to many previous studies, the results of our analysis indicate a protective (in relation to breast cancer) effect of normal body weight. Unfortunately, Polish society - including children belongs to the infamous top countries in which the percentage of overweight and obese people is growing the fastest (52). There is mounting evidence that correct health behaviours in early childhood and adolescence may affect the incidence of breast cancer. Therefore, maintaining normal body weight should be one of the key elements of primary prevention (53).

The strengths of our study include the observation of the omega-3/omega-6 ratio, which, to our knowledge, has not yet been previously assessed in the Polish population. Our study also showed the relationship between body weight and fish consumption and a reduced risk of breast cancer.

The major limitation of this study was the recall bias, as in all case-control studies. However, effort was made to minimise this limitation by choosing newly diagnosed consecutive patients and collecting all necessary subjects during a short period of time. Unfortunately, as some of the cases were already undergoing chemotherapy, this largely influenced their diet. The applied FFQ method may have also constituted some limitations. Women who are aware of a beneficial diet can often give underestimated amounts and, based on their knowledge, choose products that have health-promoting effects. In addition, the evaluation of PUFAs with FFQ may differ on the actual acid content of the product, which may depend on different period of harvest of food products, storage time, or method of cooking (54). The analysis also includes omega-3 from supplementation, the absorption of which can be case-specific. Due to these restrictions, it seems reasonable to elaborate with larger studies to determine the content of individual fatty acids in the blood samples. However, biomarkers may reflect different time periods of exposure, ranging from a few days to 1 year (depending on the type of biomarker used) (55).

Another limitation is that the study was only carried out among Caucasian women who have a high rate of breast cancer. Therefore, it cannot be generalised with regards to the entire population. The questionnaire does not include questions about chemotherapy, which has a significant impact on the diet of patients, and mightlikely affect the ORs and 95\% CIs.

The impact of modifiable diet components on the risk of breast cancer is still not fully understood. However, the results of our study shed light on the role of dietary fats and fatty acids in the aetiology of breast cancer. It is possible to create a dietary prevention program that would target the entire population. Replacing meat for fish twice a week minimum could be the first step towards improving breast cancer statistics in Poland. The results of the study can be a starting point for the construction of a primary breast cancer prophylaxis system in Poland.

\section{Conflicts of Interest}

We have no conflicts of interest to disclose. 


\section{Authors' Contributions}

PZ designed the study and contributed in $20 \%$ of the paper. DDB was responsible for data collection and data analysis, wrote the paper with some input from PZ and contributed in $80 \%$ of the paper.

\section{References}

1 Bray F, Ferlay J, Soerjomataram I, Siegel RL, Torre LA and Jemal A: Global Cancer Statistics 2018: GLOBOCAN Estimates of Incidence and Mortality Worldwide for 36 Cancers in 185 Countries. CA Cancer J Clin 68: 394-424, 2018. PMID: 30207593. DOI: $10.3322 /$ caac.21492

2 Chejes V, Romieu I: Nutrition and breast cancer. Maturitas 77(1): 7-11, 2014. PMID: 24215727. DOI:10.1016/j.maturitas 2013.10.004

3 Narita S, Inoue M, Saito E, Abe SK, Sawada N, Ishihara J, Iwasaki M, Yamaji T, Shimazu T, Sasazuki S, Shibuya K, Tsugane S and JPHC Study Group: Dietary fiber intake and risk of breast cancer defined by estrogen and progesterone receptor status: the Japan Public Health Center-based Prospective Study. Cancer Causes Control 28: 569-578, 2017. PMID: 28337559. DOI: $10.1007 / \mathrm{s} 10552-017-0881-3$

4 Gliniewicz A, Zielińska A, Kwiatkowska K, Dudek-Godeau D and Bielska-Lasota M: Survival in women diagnosed with breast and cervical cancer in Poland - compared to European countries, based on CONCORD - 3 Programme. Przegl Epidemiol 72(4): 499-508, 2018. DOI: 10.32394/pe.72.4.25

5 Hanf $\mathrm{V}$ and Gonder U: Nutrition and primary prevention of breast cancer: foods, nutrients and breast cancer risk. Eur J Obstet Gynecol Reprod Biol 123: 139-149, 2005. PMID: 16316809. DOI: 10.1016/j.ejogrb.2005.05.011

6 Kamińska M, Ciszewski T, Łopacka-Szatan K, Miotła P and Starosławska E: Breast cancer risk factors. Menopause Rev 14(3): 196-202, 2015. PMID: 26528110. DOI:10.5114/pm. 2015.54346

7 Brennan SF, Cantwell MM, Cardwell ChR, Velentzis LS and Woodside JV: Dietary patterns and breast cancer risk: a systematic review and meta-analysis. Am J Clin Nutr 91: 1294-1302, 2010. PMID: 20219961. DOI: 10.3945/ajcn. 2009.28796

8 Ronco AL, De Stefani E and Stoll M: Hormonal and metabolic modulation through nutrition: Towards a primary prevention of breast cancer. The Breast 19: 322-332, 2010. PMID: 20542695. DOI: $10.1016 /$ j.breast.2010.05.005

9 Hidaka BH, Kimler BF, Fabian CJ andCarlson SE: An empirically derived dietary pattern associated with breast cancer risk is validated in a nested case-control cohort from randomized primary prevention trial. Clin Nutr ESPEN 17: 8-17, 2017 PMID: 28361752. DOI: 10.1016/j.clnesp.2016.10.008

10 Blücher Ch and Stadler SC: Obesity and breast cancer: Current insights on the role of fatty acids and lipid metabolism in promoting breast cancer growth and progression. Front Endocrinol (Lausanne) 8: 293, 2017. PMID: 29163362. DOI: 10.3389/fendo.2017.00293

11 Zheng JS, Hu XJ, Zhao YM Yang J and Li D: Intake of fish and marine n-3 polyunsaturated fatty acids and risk of breast cancer: Meta-analysis of data from 21 independent prospective cohort studies. BMJ 346: f3706, 2013. PMID: 23814120. DOI: 10.1136/bmj.f3706
12 Simopoulos AP: The importance of the ratio of omega-6/omega3 essential fatty acids. Biomed Pharmacother 56: 365-379, 2002. PMID: 12442909. DOI: 10.1016/S0753-3322(02)00253-6

13 Saadatian-Elahi, M, Norat, T, Goudable, J and Riboli E: Biomarkers of dietary fatty acid intake and the risk of breast cancer: A meta-analysis. Int J Cancer 111: 584-591, 2004. PMID: 15239137. DOI: $10.1002 / \mathrm{ijc} .20284$

14 Kim JH Lee J, Jung SY and Kim J: Dietary factors and female breast cancer risk: A prospective cohort study. Nutrients 9(12), 2017. PMID: 29215604. DOI: 10.3390/nu9121331

15 Janssens $\mathrm{J}$ : The paradigms in breast cancer prevention. In: Trends in Breast Cancer Prevention. Russo J (eds.). Springer International Publishing, Switzerland, pp. 1-22, 2016. DOI: 10.1007/978-3-319-27135-4_1

16 Hall MJ, Obeid EI, Schwartz SC, Mantia-Smaldone G, Forman $\mathrm{AD}$ and Daly MB: Genetic testing for hereditary cancer predisposition: BRCA1/2, Lynch syndrome, and beyond. Gynecol Oncol 140: 565-574. 2016. PMID: 26812021. DOI: 10.1016/j.ygyno.2016.01.019

17 Ferlay JSH, Bray F, Forman D, Mathers C and Parkin DM: Estimates of worldwide burden of cancer in 2008: GLOBOCAN 2008. Int J Cancer 127: 2893-2917, 2010. PMID: 21351269. DOI:10.1002/ijc. 25516

18 Armstrong B and Doll R: Environmental factors and cancer incidence and mortality in different countries, with special reference to dietary practices. Int J Cancer 15: 617-631, 1975. PMID: 1140864. DOI: 10.1002/ijc.2910150411

19 Buell P: Changing incidence of breast cancer in JapaneseAmerican women. J Natl Cancer Inst 51: 1479-1483, 1973. PMID: 4762931. DOI: 10.1093/jnci/51.5.1479

20 Dunn JE: Breast cancer among American Japanese in the San Francisco Bay area. Natl Cancer Inst Monogr 47: 157-160, 1977. PMID: 613235.

21 McPherson K, Steel CM and Dixon JM: Breast cancerepidemiology, risk factors, and genetics. BMJ 321: 624-628, 2000. PMID: 10977847. DOI: 10.1136/bmj.321.7261.624

22 Boyd NF, Martin LJ, M. Noffel M Lockwood GA and Trichler DL: A meta-analysis of studies of dietary fat and breast cancer risk. Br J Cancer 68(3): 627-636, 1993. PMID: 8353053. DOI: 10.1038/bjc.1993.398

23 Boylan S, Welch A, Pikhart H, Malyutina S, Pajak A, Kubinova R, Bragina O, Simonova G, Stepaniak U, Gilis-Januszewska A, Milla L, Peasey A, Marmot M and Bobak M: Dietary habits in three Central and Eastern European countries: the HAPIEE study. BMC Public Health 9: 439, 2009. PMID: 19951409. DOI: 10.1186/1471-2458-9-439

24 Włodarek D and Głąbska D: Analysis of satisfaction of nutritional needs of elderly women depending on malnutrition risk. Probl Hig Epidemiol 95(2): 331-338, 2014.

25 Murff HJ, Shu XO, Li H Yang G, Wu X, Cai H, Wen W, Gao YT and Zheng W: Dietary polyunsaturated fatty acids and breast cancer risk in Chinese women: a prospective cohort study. Int J Cancer 128(6): 1434-1441, 2011. PMID: 20878979. DOI: $10.1002 / \mathrm{ijc} .25703$

26 Thiebaut AC, Chajes V, Gerber M, Boutron-Ruault MC, Joulin V, Lenoir G, Berrino F, Riboli E, Bénichou J and ClavelChapelon F: Dietary intakes of omega-6 and omega-3 polyunsaturated fatty acids and the risk of breast cancer. Int $\mathrm{J}$ Cancer 124(4): 924-931, 2009. PMID: 19035453. DOI:10.1002/ ijc. 23980 
27 Gago-Dominguez M, Yuan JM, Sun CL, Lee HP and Yu MC: Opposing effects of dietary n-3 and n- 6 fatty acids on mammary carcinogenesis: the Singapore Chinese Health Study. Br J Cancer 89(9): 1686-1692, 2003. PMID: 14583770. DOI:10.1038/ sj.bjc. 6601340

28 Bougnoux P. Giraudeau B and Couet C: Diet, cancer, and the lipidome. Cancer Epidemiol Biomarkers Prev 15(3): 416-421, 2006. PMID: 16537692. DOI: 10.1158/1055-9965.EPI-05-0546

29 Bagga D, Anders KH, Wang HJ and Glaspy JA: Long-chain n3-to-n-6 polyunsaturated fatty acid ratios in breast adipose tissue from women with and without breast cancer. Nutr Cancer 42(2): 180-185, 2002. DOI: 10.1207/S15327914NC422_5

30 Maillard V, Bougnoux P, Ferrari P, Jourdan ML, Pinault M, Lavillonnière F, Body G, Le Floch $\mathrm{O}$ and Chajès V: N-3 and N6 fatty acids in breast adipose tissue and relative risk of breast cancer in a case-control study in Tours, France; Int J Cancer 98(1): 78-83, 2002. PMID: 11857389. DOI: 10.1002/ijc.10130

31 Simonsen N, Van't Veer P, Strain JJ, Martin-Moreno JM, Huttunen JK, Navajas JF, Martin BC, Thamm M, Kardinaal AF, Kok FJ and Kohlmeier L: Adipose tissue omega-3 and omega-6 fatty acid content and breast cancer in the EURAMIC study. European Community Multicenter Study on Antioxidants, Myocardial Infarction, and Breast Cancer. Am J Epidemiol 147(4): 342-352, 1998. PMID: 9508101. DOI: 10.5167/uzh-125127

32 Goodstine SL, Zheng T, Holford TR, Ward BA, Carter D, Owens PH and Mayne ST: Dietary (n-3)/(n-6) fatty acid ratio: possible relationship to premenopausal but not postmenopausal breast cancer risk in U.S. women. J Nutr 133(5): 1409-1414, 2003. PMID: 12730430. DOI: 10.1093/jn/133.5.1409

33 Chajès V, Torres-Mejía G, Biessy C, Ortega-Olvera C, AngelesLlerenas A, Ferrari P, Lazcano-Ponce E and Romieu I: $\omega-3$ and $\omega-6$ polyunsaturated fatty acid intakes and the risk of breast cancer in mexican women: Impact of obesity status. Cancer Epidemiol Biomark Prev 21(2): 319-326, 2012. PMID: 22194528. DOI: $10.1158 / 1055-9965$.EPI-11-0896

34 Chajès V, Hultén K, Van Kappel AL, Winkvist A, Kaaks R, Hallmans G, Lenner P and Riboli E: Fatty-acid composition in serum phospholipids and risk of breast cancer: an incident casecontrol study in Sweden. Int J Cancer 83(5): 585-590, 1999 PMID: 10521790. DOI: 10.1002/(SICI)1097-0215(19991126) 83:5<585::AID-IJC2>3.0.CO;2-Z

35 Sczaniecka AK, Brasky TM, Lampe JW, Patterson RE and White E: Dietary intake of specific fatty acids and breast cancer risk among postmenopausal women in the VITAL cohort. Nutr Cancer 64(8): 1131-1142, 2012. PMID: 23137008. DOI: $10.1080 / 01635581.2012 .718033$

36 Wirfalt E, Mattisson I, Gullberg B, Johansson U, Olsson H and Berglund G: Post-menopausal breast cancer is associated with high intakes of $x 6$ fatty acids (Sweden). Cancer Causes Control 13: 883-893, 2002. PMID: 12588084.

37 Byrne C, Rockett $\mathrm{H}$ and Holmes MD: Dietary fat, fat subtypes, and breast cancer risk: lack of an association among postmenopausal women with no history of benign breast disease. Cancer Epidemiol Biomark Prev 11: 261-265, 2002. PMID: 11895875

38 Lof M, Sandin S, Lagiou P, Hilakivi-Clarke L, Trichopoulos D, Adami HO and Weiderpass E: Dietary fat and breast cancer risk in the Swedish women's lifestyle and health cohort. Br J Cancer 97: 1570-1576, 2007. PMID: 17940510. DOI:10.1038/sj.bjc. 6604033
39 Knekt P, Albanes D, Seppanen R, Aromaa A, Järvinen R, Hyvönen L, Teppo L and Pukkala E: Dietary fat and risk of breast cancer. AJCN 52: 903-908, 1990. DOI: 10.1093/ajen/ 52.5 .903

40 Sieri S, Krogh V, Ferrari P, Berrino F, Pala V, Thiébaut AC, Tjønneland A, Olsen A, Overvad K, Jakobsen MU, ClavelChapelon F, Chajes V, Boutron-Ruault MC, Kaaks R, Linseisen J, Boeing H, Nöthlings U, Trichopoulou A, Naska A, Lagiou P, Panico S, Palli D, Vineis P, Tumino R, Lund E, Kumle M, Skeie G, González CA, Ardanaz E, Amiano P, Tormo MJ, MartínezGarcía C, Quirós JR, Berglund G, Gullberg B, Hallmans G, Lenner P, Bueno-de-Mesquita HB, van Duijnhoven FJ, Peeters $\mathrm{PH}$, van Gils CH, Key TJ, Crowe FL, Bingham S, Khaw KT, Rinaldi S, Slimani N, Jenab M, Norat T and Riboli E: Dietary fat and breast cancer risk in the European Prospective Investigation into Cancer and Nutrition. AJCN 88: 1304-1312, 2008. PMID: 18996867. DOI: 10.3945/ajen.2008.26090

41 Kruk J and Marchlewicz M: Dietary fat and physical activity in relation to breast cancer among polish women. Asian Pac J Cancer Prev 14(4): 2495-2502, 2014. PMID: 23725163. DOI: 10.7314/apjcp.2013.14.4.2495

42 Lee MM, Chang IY, Horng CF, Chang JS, Cheng SH and Huang A: Breast cancer and dietary factors in Taiwanese women. Cancer Causes Control 16(8): 929-937, 2005. PMID: 16132802. DOI: $10.1007 / \mathrm{s} 10552-005-4932-9$

43 Khankari NK, Bradshaw PT, Steck SE, He K, Olshan AF, Shen J, Ahn J, Chen Y, Ahsan H, Terry MB, Teitelbaum SL, Neugut A, Santella RM and Gammon MD: Polyunsaturated fatty acid interactions and breast cancer incidence: a population-based casecontrol study on Long Island, New York. Ann Epidemiol 25(12): 929935, 2015. PMID: 26452606. DOI:10.1016/j.annepidem.2015.09.003

44 Prentice RL, Caan B, Chlebowski RT, Patterson R, Kuller LH, Ockene JK, Margolis KL, Limacher MC, Manson JE, Parker LM, Paskett E, Phillips L, Robbins J, Rossouw JE, Sarto GE, Shikany JM, Stefanick ML, Thomson CA, Van Horn L, Vitolins MZ, Wactawski-Wende J, Wallace RB, Wassertheil-Smoller S, Whitlock E, Yano K, Adams-Campbell L, Anderson GL, Assaf AR, Beresford SA, Black HR, Brunner RL, Brzyski RG, Ford L, Gass M, Hays J, Heber D, Heiss G, Hendrix SL, Hsia J, Hubbell FA, Jackson RD, Johnson KC, Kotchen JM, LaCroix AZ, Lane DS, Langer RD, Lasser NL and Henderson MM: Lowfat dietary pattern and risk of invasive breast cancer: the Women's Health Initiative Randomized Controlled Dietary Modification Trial. Jama 295: 629-642, 2006. PMID: 16467232. DOI: $10.1001 /$ jama.295.6.629

45 Boyd NF, Stone J, Vogt KN, Connelly BS, Martin LJ and Minkin S: Dietary fat and breast cancer risk revisited: a metaanalysis of the published literature. BR J Cancer 89: 1672-1685, 2003. PMID: 14583769. DOI: 10.1038/sj.bjc.6601314

46 Huerta-Yépez S, Tirado-Rodriguez AB and Hankinson O: Role of diets rich in omega- 3 and omega- 6 in the development of cancer. Bol Med Hosp Infant Mex 73(6): 446-456, 2016. PMID: 29421289. DOI: 10.1016/j.bmhimx.2016.11.001

47 Molendi-Coste O, Legry V and Leclercq IA: Why and how meet n-3 PUFA dietary recommendations? Gastroenterol Res Pract 2011: 364040, 2011. DOI: 10.1155/2011/364040

48 Poland, Eurofish International Organization. Available at: https://www.eurofish.dk/poland

49 Haraldsdottir A, Steingrimsdottir L, Valdimarsdottir UA, Aspelund T, Tryggvadottir L, Harris TB, Launer LJ, Mucci LA, 
Giovannucci EL, Adami HO, Gudnason V and Torfadottir JE: Early life residence, fish consumption, and risk of breast cancer. Cancer Epidemiol Biomarkers Prev 26: 346-354, 2017. PMID: 27765796. DOI: 10.1158/1055-9965.EPI-16-0473-T

50 Nitrayová S, Brestenský M, Heger J, Patráš P, Rafay J and Sirotkin A: Amino acids and fatty acids profile of chia (Salvia hispanica L.) and flax (Linum usitatissimum L.) seed. Potravinarstvo 8(1): 72-76, 2014. DOI: $10.5219 / 332$

51 Lee K, Kruper L, Dieli-Conwright $\mathrm{Ch}$ and Mortimer JE: The impact of obesity on breast cancer diagnosis and treatment. Curr Oncol Rep 21: 41, 2019. PMID: 30919143. DOI: 10.1007/ s11912-019-0787-1

52 Kovacs V, Śliż D, Parol D and Zgliczynski WS: WHO Report: Reducing childhood obesity in Poland by effective policies. World Health Organization, 2017. Available at: http://www.euro.who.int/ __data/assets/pdf_file/0011/350030/Reducing-childhood-obesityin-Poland_final_WEB.pdf?ua $=1$
53 Seiler A, Chen MA, Brown RL and Fagundes ChP: Obesity, dietary factors, nutrition, and breast cancer risk. Curr Breast Cancer 10(1): 14-27, 2018. PMID: 30662586. DOI: 10.1007/ s12609-018-0264-0

54 Echarte M, Zulet MA and Astiasaran I: Oxidation process affecting fatty acids and cholesterol in fried and roasted salmon. J Agric Food Chem 49: 5662-5667, 2001. PMID: 11714374. DOI: $10.1021 / \mathrm{jf0} 10199 \mathrm{e}$

55 Arab L: Biomarkers of fat and fatty acid intake. J Nutr 3(3): 925S-932S, 2003. PMID: 12612178. DOI:10.1093/jn/133.3.925S

Received October 7, 2019

Revised October 24, 2019

Accepted October 30, 2019 